\title{
GITELMAN SYNDROME
}

\author{
Yulistia Asmi ${ }^{1)}$, Harnavi Harun ${ }^{2)}$ \\ ${ }^{1}$ Fakultas Kedokteran, Universitas Andalas, Bagian Penyakit Dalam RSUP M. Djamil Padang \\ email: yulistia.asmi1@gmail.com \\ ${ }^{2}$ Fakultas Kedokteran, Universitas Andalas, Bagian Penyakit Dalam RSUP M. Djamil Padang
}

Submitted: 24-03-2020, Reviewer: 30-03-2020, Accepted: 30-03-2020

\begin{abstract}
Abstrak
Sindroma Gitelman, dikenal sebagai hipokalemia-hipomagnesemia familial, merupakan kelainan tubular autosom resesif yang ditandai dengan alkalosis metabolik, hipokalemik dengan hipomagnesemia dan hipokalsiuria. Sindrom Gitelman muncul pada usia remaja atau dewasa muda namun sering tidak terdiagnosis sampai dewasa. Sindroma Gitelman merupakan penyakit tubular renal yang paling sering pada ras kaukasian, dengan prevalensi 1:40000. Gejala klinis berupa cepat lelah dan kelemahan umum, tetani, parestesia, poliuria, atau nokturia. Sindrom Gitelman berat dapat berupa perubahan status mental, kejang, rabdomiolisis, kondrokalsinosis, dan aritmia ventrikel. Telah dilaporkan pasien laki-laki usia 19 tahun dengan keluhan utama lemah pada keempat anggota gerak disertai kram dan kesemutan, poliuria, nokturia, sesak nafas, dan berdebar-debar. Pada pemeriksaan fisik ditemukan kekuatan motorik keempat ekstremitas menurun. Pemeriksaan penunjang ditemukan kadar kalium serum 1,9 mmol/L, magnesium serum 1,5 g/dL, analisa gas darah kesan alkalosis metabolik, kalium urin $270 \mathrm{mmol} / 24 \mathrm{jam}$, magnesium urin 99,84 g/24 jam, kalsium urin 54,7 mg/24 jam, serta hitung transtubular K gradient sebesar 53,02. Terapi pada pasien adalah terapi substitusi dengan pemberian kalium intravena.
\end{abstract}

Kata kunci : Sindrom Gitelman, hipokalemia, alkalosis metabolik, hipomagnesemia, hipokalsiuria

\begin{abstract}
Giteman syndrome, known as familial hypokalemia-hypomagnesemia, is an autosomal recessive tubular kidney disorder that is characterized by hypokalemia, metabolic alkalosis, hypomagnesemia, and hypocalciuria. Gitelman syndrome usually accurs in adolescents or young adults but is often not diagnosed until adult. Gitelman syndrome prevalence is estimated at $1: 40.000$. Clinical manifestation include fatigue and general weakness, tetany, paresthesias, polyuria, or nocturia. Severe complication due to Gitelman syndrome include changes in mental status, focal seizure, rhabdomiolysis, chondrocalcinosis, and ventricular arrhythmia. It has been reported a nineteen years old man patient with chief complaint weakness of whole extremities accompaned by numbness, plyuria, nocturia, breathlessness, and palpitation. Physical examination found decrease of motoric power at all four extemities. Laboratory investigations found serum pottasium levels of 1,5 g/dL, blood gases analysis suggesting metabolic alcalosis, urine potasiun $270 \mathrm{mmol} / 24$ hours, urine magnesium 99,84 g/24 hous, urine calcium 54,7 mg/24 hours, gradient $K$ transtubular count 53,02. The patient was given substitution therapy with intravenous pottasium.
\end{abstract}

Keywords: Gitelman syndrome, hypokalemia, metabolic alcalosis, hypomagnesemia, hypocalciuria

\section{PENDAHULUAN}

Sindrom Gitelman adalah gangguan tubular ginjal bersifat autosom resesif yang ditandai dengan hipokalemia, alkalosis metabolik, hipomagnesemia, dan hipoklasiuria. ${ }^{1}$ Prevalensi sindrom Gitelman diperkirakan 1-10:40.000, berpotensi lebih tinggi di Asia. ${ }^{2}$ Gejala biasanya baru muncul 
setelah usia 6 tahun dan terdiagnosis saat usia remaja atau dewasa muda, namun sering tidak terdiagnosis sampai akhir masa anak-anak bahkan dewasa. Sindrom Gitelman merupakan tubulopati yang bersifat autosomal resesif dengan mutasi pada gen SLC12A3 yang mengkode thiazide-sensitive $\mathrm{Na}-\mathrm{Cl}$ co-transporter (NCCT). ${ }^{3}$

\section{MANIFESTASI KLINIS}

Gejala sindrom gitelman berupa episode tetani (khususnya saat demam atau kehilangan magnesium ekstra karena muntah/ diare), parestesia, cepat lelah atau kelemahan umum setelah melakukan kegiatan sehari-hari, poliuria, atau nokturia. ${ }^{4}$ Pertumbuhan normal pada sindrom Gitelman, tapi bisa terjadi retardasi pada hipokalemia dan hipomagnesemia berat. ${ }^{5}$

\section{LABORATORIUM}

Temuan laboratorium pada sindrom Gitelman berupa hipokalemia, alkalosis metabolik, hipomagnesemia dan hipokalsiuria. Konsentrasi magnesium normal kadang ditemukan pada sindrom gitelman (sehingga kadang terjadi false diagnosis dengan sindrom Bartter). Eksresi prostaglandin urin normal dan fungsi ginjal dalam batas normal. ${ }^{6}$

\section{PENATALAKSANAAN}

Pasien sindrom Gitelman asimptomatik tidak perlu diberikan terapi, hanya diperlukan kontrol rutin 1-2 kali tiap tahun. Pasien dengan gejala adanya kelelahan, kelemahan otot, konstipasi, aritmia, tetani, kram, parastesia, nyeri otot maka kadar kalium dan magnesium harus dievaluasi. Normalisasi kadar magnesium sulit dicapai karena pemberian magnesium dosis tinggi dapat menyebabkan diare. Terapi magnesium klorida dapat diberikan secara oral dengan dosis inisial 3 $\mathrm{mmol} / \mathrm{m}^{2} / 24 \mathrm{jam}$ atau $4-5 \mathrm{mg} / \mathrm{kgBB} / 24 \mathrm{jam}$ dibagi dalam 3-4 dosis. Dalam kasus terjadinya tetani akut, $\mathrm{MgCl}_{2} 20 \%$ dapat diberikan intravena $(0,1 \mathrm{mmol} \mathrm{Mg} / \mathrm{kg})$, dapat diulang tiap 6 jam. $^{7}$

Indikasi koreksi kalium dibagi dalam :

- Indikasi mutlak ; pada pasien sedang dalam pengobatan digitalis, pasien dengan ketoasidosis diabetik, pasien dengan kelemahan otot pernafasan dan pasien dengan hipokalemia berat $(<2$ meq/L ).

- Indikasi kuat ; kalium harus diberikan dalam waktu yang tidak terlalu lama yaitu pada keadaan insufisiensi koroner/ iskemia otot jantung, ensefalopati hepatik, dan pasien menggunakan obat yang dapat menyebabkan perpindahan kalium dari ekstra ke intrasel.

- Indikasi sedang ; pemberian kalium tidak perlu segera seperti pada hipokalemia ringan (3-3,5 meq/L ).

Perkiraan untuk setiap penurunan kadar kalium serum $1 \mathrm{mEq} / \mathrm{L}$, defisit kalium sekitar 200-400 Meq. Pasien dengan kadar kalium serum 2,5-3,5 $\mathrm{mEq} / \mathrm{L}$ dapat diberikan terapi substitusi oral. ${ }^{7}$

\section{ILUSTRASI KASUS}

Pasien laki-laki usia 19 tahun datang ke IGD RSUP Dr. M. Djamil Padang dengan keluhan utama kelemahan keempat anggota gerak semakin meningkat sejak 2 hari yang lalu. Awalnya kedua tungkai lemah menyebabkan kesulitan berjalan sehingga harus dipapah kemudian pasien kesulitan untuk memegang benda. Lamakelamaan pasien tidak bisa menggerakkan kedua tangan dan kakinya. Keluhan diikuti kebas dan kesemutan pada keempat anggota gerak. Keluhan tersebut sudah dirasakan sejak 8 bulan yang lalu, hilang timbul. Keluhan tersebut muncul bila pasien terlalu lelah. 
Buang air kecil banyak sudah dialami oleh pasien sejak 8 bulan yang lalu, minum air 8-10 gelas perhari, frekuensi buang air kecil 6-8 kali perhari, riwayat sering bangun tengah malam karena buang air kecil ada, pasien bisa 2-3 kali buang air kecil saat malam hari.

Pasien datang ke IGD dengan kesadaran kompos mentis, tekanan darah 110/70 mmHG, frekuensi napas $20 \mathrm{x} / \mathrm{menit}$, frekuensi nadi $84 \mathrm{x} /$ menit dan suhu tubuh $37,1^{\circ} \mathrm{C}$. Pada pemeriksaan fisik didapatkan penurunan refleks fisiologis, dan penurunan kekuatan motorik keempat ekstremitas.

$$
\text { Pada pemeriksaan penunjang }
$$
didapatkan kadar $\mathrm{Hb}$ 15,3 gr/dl, leukosit $5250 / \mathrm{mm}^{3}$ dengan hitung jenis 0/2/10/58/36/4 dan trombosit 232.000/. $\mathrm{mm}^{3}$. Pada pemeriksaan kimia klinik didapatkan kadar natrium $140 \mathrm{mmol} / \mathrm{l}$, kalium 1.5 $\mathrm{mmol} / \mathrm{l}$, klorida $98 \mathrm{mmol} / \mathrm{l}$, magnesium 1.5 $\mathrm{g} / \mathrm{dl}$, ureum $29 \mathrm{mg} / \mathrm{dl}$, kreatinin $0,8 \mathrm{mg} / \mathrm{dl}$. Hasil analisis gas darah menunjukkan $\mathrm{pH}$ 7,49, pCO2 $23 \mathrm{mmHg}$, pO2 $258 \mathrm{mmHg}$, HCO3- 28,2 mmol/L, SO2 $99 \%$. Pada pemeriksaan urin didapatkan kadar natrium urin $53 \mathrm{mmol} / \mathrm{L} / 24$ jam, kalium urin 270 mmol/L/24 jam, klorida urin $153 \mathrm{mmol} / \mathrm{L} / 24$ jam, kalsium urin 54,7 $\mathrm{mg} / 24$ jam, osmolaritas urin $662 \mathrm{mOsmol} / \mathrm{kgH} 2 \mathrm{O}$, Osmolaritas serum $299 \mathrm{mOsmol} / \mathrm{kgH} 2 \mathrm{O}$ dan Trans tubular Kalium Gradient (TTKG) 53,02 (TTKG > 4 menunjukkan peningkatan sekresi Kalium di tubulus distal).

Pasien diberikan terapi kalium intravena dan saat rawat jalan dilanjutkan dengan pemberian kalium secara oral.

\section{DISKUSI}

Telah dirawat pasien laki-laki 19 tahun dengan diagnosis akhir sindrom Gitelman.

Diagnosis pada pasien ditegakan dari anamnesis, pemeriksaan fisik dan pemeriksaan penunjang. Pasien datang dengan kelemahan ekstremitas dan sering BAK. Pada pemeriksaan fisik didapatkan kekuatan motorik keempat ekstremitas menurun. Pada pemeriksaan penunjang didapatkan adanya hipokalemia berat, hipomagnesemia, hipokalsiuria, analisa gas darah dengan kesan alkalosis metabolik. ${ }^{7}$

Sindrom Gitelman sering tidak terdiagnosis sampai akhir masa kanak-kanak atau bahkan dewasa. Keluhan keram, parestesia dan kelelahan sering terjadi. ${ }^{8,9}$ Manifestasi yang berat berupa onset muda (sebelum usia 6 tahun), retardasi mental, kondrokalsinosis, rabdomiolisis, kelemahan dan aritmia ventrikuler. ${ }^{10}$

Pasien datang dengan kondisi berat yaitu kelemahan otot napas sehingga menimbulkan kegagalan pernafasan dan penurunan kesadaran. Kelemahan otot napas merupakan akibat dari hipokalemia berat. ${ }^{11,12}$ Beltagi et al (2015) menemukan komplikasi yang berat akibat komplikasi GS yaitu mengantuk, perubahan status mental dan kejang fokal. ${ }^{13}$

Mekanisme hipomagnesemia pada sindrom Gitelman belum sepenuhnya diidentifikasi. Satu studi menyatakan bahwa hilangnya co-transporter $\mathrm{Na}-\mathrm{Cl}$ mengarah ke renovasi struktural utama tubulus distal ginjal, yang ditandai perubahan glomerular dan fungsi tubular. ${ }^{14,15}$ Hipokalsiuria pada sindrom Gitelman diperkirakan akibat dari up-regulasi kompensasi reabsorpsi kalsium tubulus proksimal. ${ }^{16}$

Diagnosis sindrom Gitelman didasarkan pada gejala klinis dan kelainan biokimia, yang meliputi hipomagnesemia, hipokalemia, alkalosis metabolik, dan hipokalsiuria. Hipomagnesemia dapat tidak ditemukan. Kriteria untuk menegakkan diagnosis sindrom Gitelman adalah dengan melakukan identifikasi mutasi gen SLC12A3. ${ }^{17}$

Terapi pada pasien adalah dengan pemberian terapi substitusi dimana diberikan terapi kalium intravena. ${ }^{18}$ Indikasi pemberian kalium pada pasien adalah mutlak karena ditemukan adanya kelemahan 
otot pernapasan akibat hipokalemia berat. Selanjutnya setelah terapi intravena dapat diberikan terapi oral pada pasien. Hal ini untuk menjaga kadar kalium pasien tetap stabil. ${ }^{19}$

Konseling genetik penting karena sindrom Gitelman adalah autosomal resesif. Pasien dewasa dengan sindrom Gitelman berisiko rendah untuk memiliki anak-anak dengan sindrom Gitelman ( 1 dalam 400). Diagnosis antenatal untuk sindrom Gitelman belum disarankan karena prognosis yang baik pada sebagian besar pasien. ${ }^{3}$ Secara umum, prognosis jangka panjang sindrom Gitelman sangat bagus. Namun, tingkat beratnya kelelahan dapat menghambat aktivitas sehari-hari pasien. Perkembangan menjadi insufisiensi ginjal sangat jarang terjadi. ${ }^{20}$

\section{UCAPAN TERIMAKASIH}

Terima kasih kepada dr. Harnavi Harun, Sp.PD-KGH yang telah memberikan bimbingan dalam menyelesaikan jurnal ini. Semoga amalan dan kebaikan beliau mendapat balasan dari Allah SWT.

\section{REFERENSI}

1. Merwe PD, Rensburg MA, haylett WL, Bardien S, davids MR. Gitelman syndrome in a South Africanfamily presenting with hypokalaemia andunusual food cravings. BMC Nephrology. 2017; 18:38: 1-8.

2. Blanchard A, Bockenhauer D, Bolignano D, Calo LA, Cosyns E, devuyst $\mathrm{O}$ et al. Gitelman syndrome: consensus and guidance froma Kidney Disease: Improving Global Outcomes(KDIGO) Controversies Conference. Kidney International.2017 Jan; 91(1): 24-33.

3. Konoers NV, Levtchenko E. Gitelman Syndrome. Orphanet J Rare Disease. Nijmegen University.2008; 3:22: 1-6.
4. Riveira ME, Chang Q, Godefroid N, Hoenderop JG, Dahan K, Devuyst O. Transcriptional and functional analyses of SLC12A3 mutations: new clues for the pathogenesis of Gitelman syndrome. J Am Soc Nephrol, 2007 Apr; 18(4): 1271-83.

5. Rose, BD, Post, TW, Clinical Physiology of Acid-Base and Electrolyte Disorders, 5th ed, McGrawHill, New York. 2001. 857-63.

6. Shibli AA, Narchi H. Bartter and Gitelman syndromes: Spectrum of clinical manifestations caused by different mutations. World J Zhi ZN. Expert consensus for the diagnosis and treatment of patients with Gitelman syndrome. 2017 Sep;56(9):712-6.

7. Marques MG, Silva C, Ferreira E, Maia P, Carreira A, Campos M. Gitelman syndromewith hyponatraemia,a rare presentationNefrologia. 2014;34(2):2668

8. Pieter D, Megan A. Rensburg, Haylett WL, Bardien S, Davids R. Gitelman syndrome in a South African family presenting with hypokalaemia and unusual food cravings. BMC Nephrol. 2017; 18(1): 1-8

9. Cruz DN, Shaer AJ, Bia MJ, Lifton RP, Simon DB. Gitelman's syndrome revisited: anevaluation of symptoms and health-related quality of life. Kidney Int.2001;59:710-7.

10. Pachulski RT, Lopez F, Sharaf R. Gitelman's not-so-benign syndrome.N Engl J Med. 2005;353:850-1.

11. Peters M, Jeck N, Reinalter S, Leonhardt A, Klaus GG, Konrad M. Clinical presentation of geneticallydefined patients with hypokalemic salt-losing tubulopathies. Am J Med.2002;112:18390.

12. Beltagi AE, Norbash A, Vattoth $\mathrm{S}$. "Novel brain MRIabnormalities in 
Gitelman syndrome. Neuroradiology

Journal. 2015; 28(5):523-8.

13. Fujimura J, Nozu K, Yamamura T, Minamikawa S, Nakanishi $\mathrm{K}$, Horinouchi T. Clinical and Genetic Characteristics in Patients With Gitelman Syndrome. Kidney Int Rep. 2019; 4: 119-25.

14. Akhoulf, Nakhoul N, Dorman E, Berger, Skorecki K, Magen D. "Gitelman's syndrome: a pathophysiological and clinical update". Endocrine (Review). 2012. 41(1): 53-7

15. Berry MR, Robinson c, Frankl FE.Unexpected clinical sequelae of Gitelman syndrome: hypertension in adulthood is common and females have higherpotassium requirements. Nephrol Dial Transplant. 2013; 28: 1533-42.

16. Unwin RJ, Luft CF, Shirley DG. Pathophysiology and Management of Hypokalemia : a clinical perspective. Journal of Nature Reviews Nephrology; 2011; 7(2): 75-84.

17. Lim S. Clinical Practice Approach to Hypokalemia.Journal of Indonesia Internal Medicine. 2007; 39(1): 56-64.

18. Ashurst J, Sergent S, Wagner BJ, Kim J. Evidence-Based Management Of Potassium Disorders In The Emergency Department. EB Medicine.2016;18(11): S1-S2.

19. Shahzad MA, Mukhtar M, Ahmed A, Ullah W, Saeed R, hamid M. Gitelman Syndrome: A Rare Cause of Seizure Disorder and aSystematic Review. Case RepMed. 2019; 4(1). 1-8. 